\title{
GAMBARAN UPAYA IBU DALAM MEMBERIKAN STIMULASI TUMBUH KEMBANG PADA ANAK YANG PERNAH TERINFEKSI CYTOMEGALOVIRUS
}

\author{
Noor Yunida Triana ${ }^{1}$ \\ ${ }^{1}$ Program Studi S1 Keperawatan Universitas Harapan Bangsa Purwokerto \\ noor.triana@yahoo.co.id
}

\begin{abstract}
ABSTRAK
Cytomegalovirus merupakan penyebab utama infeksi kongenital dan dianggap sebagai infeksi berat yang mengancam nyawa. Anak yang pernah terinfeksi Cytomegalovirus (CMV) dapat mengalami disabilitas dan keterlambatan tumbuh kembang. Penelitian ini bertujuan memperoleh gambaran mengenai upaya ibu dalam memberikan stimulasi tumbuh kembang pada anak yang pernah terinfeksi CMV. Metode penelitian adalah deskriptif kualitatif dengan pendekatan fenomenologi melalui wawancara semi terstruktur pada tujuh ibu. Desain penelitian ini berupaya mengeksplorasi, mengenalisis dan menjelaskan fenomena dari pengalaman ibu secara luas, terperinci dan mendalam. Terdapat empat langkah dalam proses penelitian fenomenologi deskriptif, yaitu: bracketing, intuisi, analisis dan interpretasi. Penelitian ini mengidentifikasi empat tema: menjadi caregiver, pencarian pengobatan, memberikan stimulasi tumbuh kembang secara optimal, dan usaha latihan di tempat terapi. Hasil penelitian ini terhadap pelayanan keperawatan yaitu perawat dapat menginisiasi pembentukan peer group untuk mendukung dan membantu perjuangan ibu-ibu yang memiliki anak yang pernah terinfeksi CMV.
\end{abstract}

Kata kunci: perjuangan ibu, stimulasi, tumbuh kembang, cytomegalovirus

\begin{abstract}
Cytomegalovirus is the main cause of congenital infections and is considered a severe infections that dangerous. A child that ever infected Cytomegalovirus (CMV) may experience disability and delayed growth and development. The study aim to obtain an overview of the mother's struggle in providing growth stimulation in children who have been infected with CMV. The research method was descriptive qualitative with a phenomenological approach through semistructured interviews with seven mothers. The design of this study to explore, analyze and explain the phenomena of the mother's experience in detail and in-depth manner. There are four steps in this descriptive phenomenology research, are: bracketing, intuition, analysis and interpretation. This study identified four themes: being a caregiver, treatment efforts, provide stimulation of growth and development by optimum and efforts to provide training at the therapy site. The results of this study on nursing care is nurses can initiate the formation of peer group to support and assist the struggles of the mothers who have children who have been infected with CMV.

Keyword: struggle's mother, stimulation, growth and development, Cytomegalovirus
\end{abstract}

\section{PENDAHULUAN}

Cytomegalovirus

(CMV)

merupakan penyebab infeksi kongenital

dan infeksi berat yang mengancam

nyawa. Virus ini dapat menimbulkan

sindrom klinis yang luas pada bayi,

mulai dari infeksi yang tidak menimbulkan gejala hingga ensefalitis

fetal serta kerusakan perkembangan

sistem saraf pusat (Rudolph et al., 2007).

Penelitian menunjukkan angka kejadian infeksi CMV kongenital sekitar $\quad 30-50 \%$ dengan tingkat 
Viva Medika: Jurnal Kesehatan, Kebidanan, dan Keperawatan, 11 (02), Maret 2019

Noor Yunida Triana (Gambaran Upaya Ibu Dalam Memberikan Stimulasi Tumbuh Kembang Pada Anak Yang Pernah Terinfeksi Cytomegalovirus )

keparahan yang bervariasi (Revello et al., 2014). Sekitar 30.000-40.000 bayi lahir terinfeksi CMV setiap tahun di Amerika Serikat (Bale, 2012). Angka kejadian CMV di Indonesia belum diketahui secara pasti, tetapi berdasarkan penelitian ditemukan sekitar $87.8 \%$ masayarakat mengalami seropositive (Suromo, 2007).

Terdapat beberapa dampak negatif infeksi CMV terhadap anak dan orang tua. Anak dapat mengalami hospitalisasi karena harus menjalani perawatan (Wong et al., 2009). Dampak negatif lain infeksi CMV antara lain: gangguan perkembangan, gangguan pendengaran dan mikrosepal (Ikatan Dokter Anak Indonesia, 2008). Sedangkan dampak CMV bagi orang tua dan anggota keluarga yaitu kecemasan dan ketakutan dengan kondisi anak yang dirawat (Ball, Bindler, \& Cowen, 2010).

Hasil penelitian yang dilakukan Parks (2012) menggambarkan bahwa ibu merasa syok dan menyangkal saat pertama kali mengetahui bahwa anak mengalami kecacatan akibat CMV. Ibu berjuang untuk memenuhi kebutuhan fisik dan psikologis anak dan memberikan stimulasi tumbuh kembang pada anak.
Orang tua memiliki peran sentral dalam memberikan dukungan dan perawatan untuk mengatasi proses pemulihan anak-anak yang sakit (Alisic, 2014). Orang tua terutama ibu menjadi sumber utama dalam memberikan bantuan dan kenyamanan selama anak sakit, termasuk saat anak mengalami CMV (Bowden \& Greenberg, 2010). Berdasarkan perannya, ibu lebih banyak bersama anak, memberikan perawatan dan memenuhi kebutuhan anak di rumah, sehingga ibu memiliki pengalaman yang banyak dalam memberikan perawatan pada anak sakit (Wong et al., 2009).

Belum terdapat penelitian mengenai upaya ibu dalam memberikan stimulasi tumbuh kembang pada anak yang pernah terinfeksi CMV di Indonesia. Jika pengalaman mengenai upaya ibu dalam memberikan stimulasi tumbuh kembang dapat dieksplorasi lebih dalam, maka tenaga kesehatan dapat menjalankan fungsi dan peran dengan optimal. Oleh sebab itu, peneliti ingin mengeksplorasi perjuangan ibu dalam memberikan stimulasi tumbuh kembang pada anak yang pernah terinfeksi CMV. 
Viva Medika: Jurnal Kesehatan, Kebidanan, dan Keperawatan, 11 (02), Maret 2019

Noor Yunida Triana (Gambaran Upaya Ibu Dalam Memberikan Stimulasi Tumbuh Kembang Pada Anak Yang Pernah Terinfeksi Cytomegalovirus )

\section{METODE PENELITIAN}

Penelitian ini menggunakan desain deskriptif kualitatif dengan pendekatan fenomenologi. Penelitian ini memahami upaya ibu dan keunikan ibu dalam memberikan stimulasi tumbuh kembang. Penelitian ini dilakukan sejak bulan April hingga Agustus 2017 di RSUD Prof. dr. Margono Soekarjo.

Tehnik sampling yang digunakan pada penelitian ini yaitu purposive sampling dengan karakteristik partisipan yaitu ibu yang memiliki anak yang pernah terinfeksi CMV dan ibu yang berupaya langsung memberikan stimulasi tumbuh kembang pada anak yang pernah terinfeksi CMV. Partisipan yang terlibat dalam penelitian ini berjumlah tujuh partisipan.

Data penelitian diambil dengan metode wawancara semi terstruktur dengan memberikan pertanyaan terbuka kepada partisipan. Wawancara disertai perekaman suara dengan alat perekam yang telah diuji sebelumnya.

Analisis data dilakukan sesuai dengan pengambilan data dan menggunakan metode Colaizzi (1978) dalam Rezaie, Khadaie, dan Yazdani (2016). Langkah awal analisis data yaitu membuat transkrip verbatim dan membaca hasil transkrip wawancara beberapa kali; mengutip pernyataan yang bermakna; mengelompokkan pernyataan yang bermakna; formulasi tema; menggabungkan tema dalam bentuk deskripsi; merumuskan hasil deskripsi dan 1 melakukan validasi mengenai hasil penelitian.

Penelitian ini telah melalui uji etik dari Komite Etik Penelitian Fakultas Ilmu Keperawatan No.92/UN2.F12.D/HKP.02.04/2017. Penelitian ini telah mendapatkan ijin penelitian dari ruang rehap medik di RSUD Prof. dr. Margono Soekarjo.

\section{HASIL DAN PEMBAHASAN}

Penelitian ini melibatkan tujuh partisipan yang telah sesuai dengan kriteria. Karakteristik partisipan dapat dilihat dari tabel berikut:

\section{Tabel 1}

Karakteristik Partisipan yang Berjuang dalam Memberikan Stimulasi Tumbuh Kembang pada Anak yang Pernah Terinfeksi CMV 
Viva Medika: Jurnal Kesehatan, Kebidanan, dan Keperawatan, 11 (02), Maret 2019

Noor Yunida Triana (Gambaran Upaya Ibu Dalam Memberikan Stimulasi Tumbuh Kembang Pada Anak Yang Pernah Terinfeksi Cytomegalovirus )

Penelitian ini mengidentifikasi empat tema, antara lain: 1) Menjadi caregiver, 2) Pencarian pengobatan, 3) Memberikan stimulasi tumbuh kembang secara optimal, 4) Usaha latihan di tempat terapi. Berikut gambaran dari tema-tema yang dihasilkan:

Tema 1: Menjadi caregiver

Perjuangan ibu sebagai caregiver meliputi belajar cara memberikan terapi, mencari informasi, memberikan stimulasi rutin, berlaku disiplin dan berusaha menjaga kesehatan anak, dan menyediakan alat terapi, seperti pernyataan berikut:

"Kalau setiap kita ke fisioterapi, lihat fisioterapisnya ngapain takrekam..." (P1)

"Terus kalau di Ortopedi sama, cara duduk sama berdiri, dilatih berdiri, sama dititah.” (P2)

"Ya, paling setiap hari aku latih." (P4)

"Padahal aku kan beli, emang dari kulit yang kuat tu, sepatu." (P1)

“Akhirnya saya beli bola...” (P2)

"Terus, ada standing juga, latihan berdiri (menunjukkan papan kayu)."

\begin{tabular}{ccccc}
\hline Inisial & $\begin{array}{c}\text { Usia } \\
\text { ibu } \\
\text { (tahun) }\end{array}$ & $\begin{array}{c}\text { Usia } \\
\text { anak } \\
\text { (bulan) }\end{array}$ & $\begin{array}{c}\text { Pekerja } \\
\text { an }\end{array}$ & $\begin{array}{c}\text { Pendidik } \\
\text { an } \\
\text { Terakhir }\end{array}$ \\
\hline Ny.Ru & 35 & 22 & Perawat & D3 Kep \\
Ny.E & 28 & 49 & Guru & S1 PAI \\
Ny.D & 29 & 26 & IRT & S1 Sastra \\
Ny.N & 26 & 39 & IRT & SMP \\
Ny.Ri & 28 & 36 & IRT & SMA \\
Ny.F & 29 & 72 & IRT & SMP \\
Ny.S & 31 & 18 & IRT & SMA \\
\hline \multicolumn{5}{c}{ “..terus pakai sepatu. Pakai back- } \\
slep, ini talinya udah." (P6)
\end{tabular}

"Iya, baby walker, udah dilatih pun, belum bisa." (P7)

"Terus anakku kakinya flat, beli sepatu, sepatu koreksi." (P5)

Tema 2: Pencarian pengobatan

Perjuangan ibu yang lain agar anak dapat seperti anak yang normal yaitu melakukan upaya pengobatan dengan mencari pengobatan alternatif, seperti pernyataan berikut:

“...kepalanya anget bisa juga karena sunti, katanya. Jadi waktu umur satu tahun, dikhitan." (P2)

"Tapi kemarin pas aku bantu pakai herbal yang dari Insinyur Juanda itu, ada perubahan sih." (P4)

“Alternatifnya pak Kyai. Sama Pak Kyai kan di daerah, hampir 3 tahun." (P6)

"Dari herbal pun sudah gitu lho." (P7) 
Viva Medika: Jurnal Kesehatan, Kebidanan, dan Keperawatan, 11 (02), Maret 2019

Noor Yunida Triana (Gambaran Upaya Ibu Dalam Memberikan Stimulasi Tumbuh Kembang Pada Anak Yang Pernah Terinfeksi Cytomegalovirus )

Tema 3: Memberikan stimulasi tumbuh kembang secara optimal

Selain hal-hal tersebut, perjuangan ibu yang lain agar anak normal adalah ibu melakukan berbagai macam cara untuk mengejar tumbuh kembang anak, salah satunya memberikan stimulasi tumbuh kembang secara optimal. Usaha ini antara lain:

a. Memberikan stimulasi pertumbuhan dengan memberikan makanan padat gizi. Berikut pernyataan partisipan:

“...daging sapi, nasi, wortel, kacang merah, sayuran hijau, tempe, tahu, dimasak, terus diblender." (P3)

"Tahu, ikan, tempe. Sayur ya sayur bening." (P4)

"...menu nasi, misalkan sama abon. Nanti siang menu makan, terus buah lagi, terus malam makan." (P5)

"Dua tahun apa ya, ya sekitar 2 tahun kan udah ngetim. Tak kasih ikan, brokoli, wortel..." (P6)

b. Memberikan stimulasi perkembangan motorik kasar. Berikut pernyataan partisipan:

"Merangkak, kakinya ditumpuan lutut, kita di belakang terus pegang kakinya, tangannya juga." (P1) “...cara duduk dari $\mathrm{R}$ terlentang, nanti dimiringkan, nanti tangannya menahan, terus duduk." (P2)

"Nglatih jalannya itu, titah tangan satu." (P3)

"Cara melakukan standing dengan memposisikan anak berdiri di papan kayu menggunakan backslep, lalu diikat dengan tali." (P4)

"Ini yang latihan jalan. Suruh pakai besi terus pakai bambu...(P5)

“...kadang dipegangin belakang, kadang pinggangnya juga....” (P6)

"Nglatih duduknya ya, waktu itu dia didudukin di kursi, taruhin bantal-bantal gitu." (P7)

c. Memberikan stimulasi bicara dan bahasa. Berikut pernyataan partisipan:

"Ya, mau mimi pas kita mau kasih mimi, ya diajarin mimi..." (P1)

"...misalnya anak saya mau minta minum, sebelum saya kasih, itu bilang dulu, mimi, mimi, gitu." (P2)

"Ya, gitu. Misale, mbah, mamah, ma-kan, ayo makan-makan, gitu." (P3)

“...kayak gini (mempraktekkan pijat oral), 3 kali, 3 kali, atas bawah...." (P4) 
“...ke mainan yang di temboktembok, maksute ini namanya apa,..." (P5)

"Nih, belajar kayak gini ya, ditulis di buku ntar di rumah dipelajari, dioral, terus AIUEO.” (P6)

"Ya, paling ngenalin tementemennya. Ngenalin kakak, embah...." (P7)

d. Memberikan stimulasi personal sosial. Berikut pernyataan partisipan:

"Lha itu, sudah saya ajari kayak gini tapi belum, belum mau rubah..." (P2)

"Kan banyak anak-anak di sini, paling dipanggilin ke sini." (P5)

"Ya, nglatih suruh salim. Daagdaag gitu." (P7)

e. Memberikan stimulasi motorik halus. Berikut pernyataan partisipan:

"Anak saya latih untuk memasukkan yang sesuai dengan bentuk bangunnya itu." (P2)

"Walaupun dia belum bisa megang, tapi suruh dilatih, gitu lho..." (P4)

"Paling megang, tangannya kan gegem kayak gini, dikasih yang bola, pokoknya yang gede-gede lah." (P5)
"Ya, gelasnya dipegang, terus tangannya saya megangin juga, biar diminum ke sini." (P6)

“...kasih piring, sama ya, diisi nasi. Terus dikasih sendok.” (P7)

Tema 4: Usaha latihan di tempat terapi

Semua perjuangan ibu tersebut ditunjang dengan usaha ibu membawa anak untuk latihan di tempat terapi khusus anak disabilitas. Latihan tersebut meliputi pelatihan terstruktur di fisioterapi dan pelatihan terstruktur di terapi wicara. Berikut pernyataan partisipan:

“...10 bulan sampai mau 2 tahun, seminggu 2 kali.” (P1)

"...saya rutin terus bu, seminggu 3 kali, kadang itu, seminggu 4 kali." (P2)

"...dipijitin sebentar. Terus habis itu, ya itu latihan sit-up, back-up, jongkok." (P3)

"Seminggu dua kali, sabtu sama minggu." (P4)

"Akhirnya dilanjut sampai sekarang, udah 1 tahun, di Dukuh Waluh.” (P6)

"Yang dilatih wicara masih dengan permainan... (P1)

"Kalau terapi wicaranya lha itu saya, terapi wicara pernah, baru sekali." (P2) 
“...mindah-mindahin warna. Terus nyebutin buah, terus ngambil-ngambil mainan kayak gituan." (P5)

"Lagi diterapi juga kan, terapi wicara juga di situ." (P6)

Beberapa tema yang telah dihasilkan, masing-masing dibahas dengan jelas. Berikut pembahasan dari masing-masing tema:

Tema 1: Menjadi caregiver

Caregiver merupakan individu yang memberikan dukungan atau merawat individu yang lain dalam kehidupan sehari-hari (Awad \& Voruganti, 2008). Caregiver juga didefinisikan sebagai orang tua (ibu atau ayah) atau anggota keluarga lainnya dari anak yang mengalami keterlambatan perkembangan (Savage \& Bailey, 2004).

Terdapat empat tahap pengalaman ibu sebagai caregiver anggota keluarga yang mengalami kondisi kronik, yaitu: tahap diagnosis, tahap ketidakseimbangan dalam menghadapi masalah, tahap upaya mengatasi masalah dan tahap terakhir bertanggungjawab terhadap kehidupan seseorang (Friedman, 2010).
Ibu melakukan berbagai upaya agar anak bisa kembali normal, salah satunya menyediakan alat terapi. Alat terapi yang disediakan oleh ibu meliputi sepatu koreksi, baby walker, standing dan bola. Papan standing dapat membantu anak yang mengalami serebral palsy untuk latihan berdiri (Lissauer \& Clayden, 2009). Kanatli, Atkas, dan Yetlin (2016) mengungkapkan beberapa ahli bedah ortopedi belum memiliki standar khusus untuk pengelolaan masalah kaki yang flat pada anak.

Tema 2: Pencarian pengobatan

Partisipan mengungkapkan mencari pengobatan alternatif dengan bantuan Pak Kyai yang dipercaya dapat memperbaiki sendi-sendi agar perkembangan motorik anak mengalami kemajuan. Sementara partisipan yang lain menggunakan obat herbal untuk penyembuhan anak.

Hal ini sesuai dengan penelitian mengenai pengobatan herbal yang terbukti menyembuhkan CMV. Obat tradisional tersebut adalah curcumin, salah satu obat tradisional Tiongkok yang diekstraksi dari rimpang ramuan curcuma longa yang terbukti digunakan 
Viva Medika: Jurnal Kesehatan, Kebidanan, dan Keperawatan, 11 (02), Maret 2019

Noor Yunida Triana (Gambaran Upaya Ibu Dalam Memberikan Stimulasi Tumbuh Kembang Pada Anak Yang Pernah Terinfeksi Cytomegalovirus )

untuk mengobati Human Cytomegalovirus (LV et al., 2015).

Tema 3: Memberikan stimulasi tumbuh kembang secara optimal

Ibu memberikan stimulasi pertumbuhan dengan cara memberikan makanan 3x sehari; membuat nasi tim yang berisi daging sapi, wortel, tempe dan sayuran; memberikan camilan sehat dan buah-buahan; serta rutin memberikan susu. Stimulasi pertumbuhan melalui pemenuhan kebutuhan gizi anak sangat diperlukan untuk meningkatkan pertumbuhan anak.

Hal ini sesuai dengan penelitian Mallard et al. (2016) yang menyatakan bahwa keragaman makanan memiliki efek yang positif terhadap pertumbuhan bayi dan anak balita. Keanekaragaman makanan tersebut meliputi makanan yang mengandung mikronutrien dan makanan sentinel (makanan kaya zat besi, protein hewani dan susu).

Adapun stimulasi perkembangan yang dilakukan ibu meliputi stimulasi motorik kasar, motorik halus, personal sosial serta bicara dan bahasa. Stimulasi motorik kasar yang dilakukan ibu meliputi: melatih anak merangkak; melatih duduk dengan cara menarik satu tangan anak saat posisi tidur; melatih anak jalan dengan titah; melatih standing dengan memposisikan anak berdiri di papan kayu; melatih anak berjalan dengan besi dan bambu yang dibentuk zig-zag, serta melatih duduk anak dengan anak didudukkan dikursi sanbil ditaruh bantal di sekitar anak. Latihan ini yang disebut dengan exercise therapy.

Exercise therapy merupakan suatu usaha yang dilakukan dalam pengobatan fisioterapi yang pelaksanaannya meliputi latihan gerak bebas baik secara aktif maupun pasif. Dasar-dasar posisi yang terdapat di dalamnya meliputi posisi lying, sitting dan standing. (Luklukaningsih, 2014).

Tema 4: Usaha latihan di tempat terapi

Upaya terakhir yang ibu lakukan yaitu membawa anak ke tempat terapi. Partisipan rutin 2 kali seminggu membawa anak untuk terapi di fisioterapi dan di tempat terapi wicara. Ibu percaya terapi dan latihan di rumah dapat meningkatkan perkembangan anak. Hal ini karena stimulasi rutin dapat melatih otot dan sistem saraf pusat sebagai pengendali gerakan.

Gerakan yang disadari merupakan gerakan kompleks yang melibatkan 
Viva Medika: Jurnal Kesehatan, Kebidanan, dan Keperawatan, 11 (02), Maret 2019

Noor Yunida Triana (Gambaran Upaya Ibu Dalam Memberikan Stimulasi Tumbuh Kembang Pada Anak Yang Pernah Terinfeksi Cytomegalovirus )

integrasi di korteks serebrum dan dapat diinisiasi berdasarkan kemauan. Gerakan ini akan semakin baik jika terus dilatih. Gerakan ini diinisiasi dan diakhiri dengan masukan dari korteks serebrum, tetapi setelah diaktifkan, jaringan interneuron sistem saraf pusat yang disebut generator pola sentral, mempertahankan aktivitas spontan yang berulang (Silverthorn, 2014).

Demikian pula dengan terapi wicara. Berdasarkan penelitian yang dilakukan oleh Sunanik (2013), didapatkan hasil bahwa terapi wicara dan sensori integrasi pada anak yang mengalami keterlambatan bicara memiliki peranan yang penting dan menentukan perkembangan bahasa anak.

\section{SIMPULAN DAN SARAN}

Berdasarkan hasil penelitian dapat disimpulkan bahwa ibu yang memiliki anak disabilitas akibat riwayat terinfeksi CMV, akan melakukan berbagai macam usaha atau perjuangan agar anak menjadi anak yang normal. Perjuangan ibu tersebut dapat mencapai keberhasilan jika mendapat dukungan dari berbagai pihak. Oleh sebab itu, perhatian dari tenaga profesional dangan dibutuhkan oleh ibu yang mempunyai anak yang pernah terinfeksi CMV.

Salah satu saran untuk pelayanan keperawatan anak yaitu diharapkan perawat dapat memberikan fasilitas kepada ibu dengan membentuk peer group, konseling dan parenting class.

\section{DAFTAR PUSTAKA}

Alisic, E., Conroy, R., Magyar, J., Babl, F.E., \& O’Donnell, M.L. (2014). Psychosocial care for seriously injured children and their families: A qualitative study among emergency department nurses and physicians. Journal of Injury, 45:1452-8.

Awad, A. G. \& Voruganti, L. N. (2008). The burden of Schizofrenia on caregivers. Journal of Pharmacoeconomics, 84 (2): 149-162.

Bale, J.F. (2012). Cytomegalovirus infection. Journal of Pediatric Neurology, 19:101-106. Doi:10.1016/j.spen.2012.02.008

Ball, J.W., Bindler, R.C., \& Cowen, K.J. (2010). Child health nursing: partnering with children and families (2nd ed.). New York, NY: Pearson

Bowden, V.R. \& Greenberg, C.S. (2010). Children and their families (2nd ed.). Philadelphia: Lipincott William \& Wilkims

Friedman, M. M. (2010). Family nursing: Research, theory and practice (fifth Edition). Corwalk CT: Appeton \& Lange. 
Ikatan Dokter Anak Indonesia. (2008). Buku ajar infeksi dan pediatri tropis. Jakarta: EGC.

Kanatli, U., Aktas, E., \& Yetkin, H. (2016). Do corrective shoes improve the development of the medial longitudinal arch in children with flexible flat feet? Journal of Orthopaedic Science, 1-5.

http://dx.doi.org/10.1016/j.jos.2 016.04.014

Lissauer, T., \& Clayden, G. Illustrated textbook of paediatric. Third Edition. USA: Mosby Elsevier.

Luklukaningsih, Z. (2014). Anatomi, fisiologi, dan fisioterapi. Yogyakarta: Nuha Medika

LV, Y., Gong, L., Wang, Z., Han, F., Liu, H., Lu, X., \& Liu, L. (2015). Curcumin inhibits human cytomegalovirus by downregulating heat shock protein 90. Journal of Molecular Medicine Reports, 12: 47894793.

DOI: 10.3892/mmr.2015.3983.

Mallard, S., Houghton, L.A., Filteau, S., Chisenga, M., Siame, J., Kasonka, L., Mullen, A., \& Gibson, R. S. (2016). Micronutrient adequacy and dietary diversity exet positive and distinct effects on linear growth in Urban Zambia infant. The Journal of Nutrition: 1-9. DOI: 10.3945/jn.116.233890.

Parks, M. (2012). Caring for a child with profound disabilities: A mother's story. Learning Disability Practice, Vol.15(5):27-30. www.learningdisablitypractice.c o.uk

Revello M.G., Lazzarotto, T., Guerra B, et al. (2014). CHIP Study
Group. A randomized trial of hyperimmune globulin to prevent congenital

cytomegalovirus. Nursing England Journal Med; 370:1316-26.

Rudd, K., \& Kocisko, D. (2014). Pediatric nursing: The critical components of nursing care. First Edition. Philadelpia: F.A. Davis Company.

Rudolph, A.M., Hoffman, I.E., \& Rudolph, C.D. (2007). Buku ajar pediatri Rudolph, Vol.1, Ed.20. Jakarta: EGC.

Savage, S. \& Bailey, S. (2004). The impact of caring on caregivers's mental health: A review of the literature. Aust. Health Rev. 27 (1): 103-109.

Silverthorn, D. U. (2014). Fisiologi manusia: Sebuah pendekatan terintegrasi. Edisi ke-6. Alih bahasa: Staf Pengajar Departemen Fisiologi Kedokteran FKUI. Jakarta: EGC.

Soetjiningsih \& Runah, I.G. (2014). Tumbuh kembang anak. Edisi 2. Jakarta: Buku Kedokteran EGC.

Suromo, L.B. (2007). Kewaspadaan terhadap infeksi cytomegalovirus serta kegunaan deteksi secara laboratorik. Pidato pengukuhan guru besar patologi klinik. Semarang: Universitas Diponegoro.

Wong, D.L. et al. (2009). Buku ajar keperawatan anak. Ed.6, Vol.1. Jakarta: Buku Kedokteran EGC. 